\title{
NESTE FASCÍCULO
}

O fascículo contém três interessantes artigos sobre a distribuição de espécies arbóreas em diferentes localidades no Estado de Minas Gerais. No Município de Coqueiral, Rocha e colaboradores (pág. 203) descrevem a comunidade arbórea de um contínuo entre floresta paludosa e de encosta, destacando a presença de diferentes habitats e a diversidade encontrada, que combina as fisionomias de ambas florestas com a do cerrado. No Município de Três Marias, Carvalho e colaboradores (pág. 329) estudando a distribuição de espécies arbóreo-arbustivas, ao longo de um gradiente de solo e topografia em um trecho de floresta ripária do Rio São Francisco, abordam possíveis correlações entre os fatores ambientais e a comunidade vegetal. Appolinário e colaboradores (pág. 347) ao investigarem a dinâmica da comunidade arbórea e de populações constituintes de uma floresta tropical semidecídua, localizada na margem do Rio Grande no Município de Bom Sucesso, abordam possíveis conseqüências de uma inundação catastrófica, ocorrida em 1992, sobre as variações na dinâmica da comunidade arbórea.

A influência da fertilidade do solo, sobre o perfil nutricional de espécies lenhosas, é discutida no artigo de Haridasan \& Araújo (pág. 295), que estudaram os padrões de distribuição de espécies nativas em duas florestas semidecíduas em Unidades de Conservação no Município de Uberlândia, também em Minas Gerais.

Giudice Neto e colaboradores (pág. 409) apresentam o sistema de reprodução do pau-brasil, Caesalpinia echinata Lam., através de isoenzimas em arboreto, usando modelos de cruzamentos mistos e cruzamentos correlacionados e discutindo os resultados em termos de amostragens para a conservação genética e coleta de sementes para a recuperação ambiental. Interessantes resultados, referentes à germinação de diásporos de aroeira (Myracrodruon urundeuva Allemão) no cerrado do Brasil Central, estão sendo apresentados por Dorneles e colaboradores (pág. 399).

Dentre os artigos referentes aos estudos ficológicos, Branco e colaboradores (pág. 267) destacam os efeitos de excesso de precipitação pluviométrica na dinâmica sucessional de uma comunidade de macroalgas em fase de reestabelecimento, em um riacho do Estado de São Paulo. Felisberto \& Rodrigues (pág. 241) apresentam o estudo da influência do gradiente longitudinal na similaridade das comunidades de distintas regiões ao longo do um eixo rio-barragem, nos Reservatórios de Rosana (Rio Paranapanema) e de Salto do Vau (Rio Iguaçu). Destaca-se, ainda nessa linha, o artigo de Pereira e Branco (pág. 305), no qual constam estudos morfométricos e morfológicos em populações de clorófitas do gênero Schizomeris Kützing, incluindo análise cariológica.

Com relação aos aspectos estruturais, Oriani e colaboradores (pág. 229) apresentam dados da anatomia de folhas, brácteas e escapos de diversas espécies de Actinocephalus (Koern.) Sano, eriocauláceas que ocorrem em campos rupestres, caracterizando anatomicamente este novo gênero proposto para a família. Rossi e colaboradores (pág. 285) apresentam o estudo da distilia e da variação das características florais, em populações da rubiácea medicinal Psychotria ipecaucuanha (Brot.) Stokes.

$\mathrm{O}$ fascículo conta com quatro excelentes artigos sobre palinologia e morfologia floral. O artigo de Santos e colaboradores (pág. 361) apresenta a biologia reprodutiva de duas espécies de Jatropha L. nos Municípios de Buíque e Arcoverde, na caatinga do Estado de Pernambuco, destacando a importância dessas plantas para o sustento das comunidades locais de animais polinizadores e, por outro lado, a relevância destes para as plantas, que dependem do fluxo de pólen entre flores masculinas e femininas. No artigo de Witter e colaboradores (pág. 319) é apresentada a progressão da floração e antese de dois cultivares de Allium cepa L., com base na freqüência de visitas de abelhas. No artigo de Nadia e Machado (pag. 255) consta o estudo da fenologia, morfologia floral, o sistema de polinização e de reprodução de Sauvagesia erecta L. e S. sprengelii A.St.-Hil. na Mata Atlântica no Parque Estadual Dois Irmãos, em Recife, no Estado de Pernambuco, destacando-se a atuação das abelhas como animais que polinizam por vibração. Por sua vez, Kaehler e colaboradores (219) caracterizam os agentes de uma comunidade de oito bromélias de quatro diferentes gêneros, em uma floresta ombrófila no Estado do Paraná, indicando a atuação do beija-flor Phaethornis eurynome (Lesson, 1832) como espécie chave para a referida comunidade.

A análise da potencialidade bioindicadora de flúor em gramíneas tropicais, realizada por Oliva e Figueiredo (pág. 389), destaca Chloris gayana Kunth. e Panicum 
maximum Jacq. cv. Colonião como espécies bioindicadoras.

$\mathrm{Na}$ área de Biologia Molecular, Feres e colaboradores (pág. 277) apresentam uma interessante avaliação dos métodos de preservação de amostras de plantas de savanas neotropicais para a obtenção de DNA para fins de estudos moleculares. Ressaltou-se a importância de se testar diferentes métodos de preservação, já que o tradicional método de secagem em sílica gel não se mostrou tão eficiente quanto os outros testados.

Iracema H. Schoenlein-Crusius Fábio de Barros

Presidente da SBSP Editor-chefe da RBB 